\title{
Co-Existence of Congenital Cystic Adenomatoid Malformation and Pulmonary Sequestration in a Newborn with Spontaneous Pneumothorax: A Case Report and Review of the Literature
}

\author{
Spontan Pnömotorakslı Bir Yenidoğanda Konjenital Kistik Adenoid Malformasyon \\ ve Pulmoner Sekestrasyon Birlikteliği: Olgu Sunumu ve Literatür Derlemesi \\ - Burcu Cebeci, ๑ Tuğba Erener Ercan, • Arslan Babayiğit, ๑ Esra Ağırgöl*, \\ ๑ Gökhan Büyükkale, ๑ Merih Çetinkaya
}

Kanuni Sultan Süleyman Training and Research Hospital, Clinic of Neonatology, Istanbul, Turkey

*Kanuni Sultan Süleyman Training and Research Hospital, Clinic of Pediatrics, istanbul, Turkey

Abstract

Congenital bronchopulmonary malformations are uncommon anomalies of infants and children presenting as congenital lobar emphysema, bronchogenic cyst, congenital cystic adenomatoid malformation (CCAM), or pulmonary sequestration (PS). CCAM is the second most common congenital lung malformation in newborns. There are five types of CCAM based on the embryologic and the histologic features. PS is defined as a mass of tissue developing in the lung but having no respiratory function. PS is classified into two types: extralobar and intralobar. Co-existence. of CCAM and PS is a rare occurrence. Hybrid lesions, especially type 2 CCAM and PS combination may have a more severe clinical progress. Herein, we report a male infant with type 2 CCAM in combination with PS who died despite both medical and surgical treatment.

Keywords: Congenital cystic adenomatoid malformation, hybrid congenital lung malformation, newborn, pulmonary sequestration
Konjenital bronkopulmoner malformasyonlar nadiren, konjenital lober amfizem, bronkojenik kist, konjenital kistik adenoid malformasyon (KKAM) veya pulmoner sekestrasyon (PS) şeklinde görülürler. KKAM yenidoğanlarda ikinci sıklıkla görülen konjenital akciğer malformasyonudur. Embriyolojik ve histolojik özelliklerine göre beş tipi mevcuttur. PS fonksiyonel olmayan akciğer kitlesi olarak tanımlanmaktadır. Intralober ve ekstralober olarak sınıflandırımaktadır. KKAM ve pulmoner sekestrasyon birlikte nadiren görülmektedir. Özellikle tip 2 KKAM ve PS birlikteliğinin olduğu hibrid lezyonlarda klinik seyir daha kötü olabilmektedir. Burada, medikal ve cerrahi tedaviye rağmen ölen tip 2 KKAM ve PS birlikteliği olan erkek bir yenidoğan sunulmuştur.

Anahtar Sözcükler: Konjenital kistik adenoid malformasyon, hibrid konjenital akciğer malformasyonu, yenidoğan, pulmoner sekestrasyon

\section{Introduction}

The development of respiratory system begins during the third gestational week and the malfunctions during the developmental period cause a group of structural anomalies defined as bronchopulmonary stromadeum malformations. Infants with these anomalies may have serious respiratory problems. Congenital cystic adenomatoid malformation (CCAM) is the second most commonly seen malformation among other congenital lung anomalies and its incidence ranges from 1 in 8.300 to 35.000 live births (1). CCAM is defined as hamartomatous lesion comprised of cystic and adenomatous elements that are arising from trachea, bronchi, bronchiole or alveolar tissue and they most often have unilateral involvement. The majority of CCAMs derives their blood supply from the pulmonary circulation. Pulmonary 
sequestration (PS) is another pulmonary malformation defined as a non-functioning lung mass that arises as an aberrant outpouching from the developing foregut with its own systemic arterial supply (2). PS is classified into two types: extralobar and intralobar. Intralobar PSs are covered with visceral pleura while extralobar PSs are covered with their own pleura. Extralobar PS is a mass of lung parenchyma that is not a part of a normal lung tissue, has no connection with tracheobronchial structures and has arterial blood supply from the aorta and its major branches. The routine use of antenatal ultrasonography (USG) enables detection of these kinds of congenital fetal anomalies in early stages of life. Several studies reported that since some congenital lesions did not fit CCAM or PS, these were usually defined as hybrid forms. In one of these forms, extralobar PS and CCAM may be defined in the same patient (3-5). Since the co-existence of CCAM and PS is a rare occurrence, we report a male infant who had type 2 CCAM in combination with extralobar PS and we reviewed the relevant literature.

\section{Case}

A male infant was born to a 40 -year-old mother at 40 weeks of gestation by cesarean section with a birth weight of 4600 grams. Apgar scores were 9 and 10 at 1 and 5 minutes, respectively. The family history was unremarkable and the parents were non-consanguineous. The prenatal USG revealed CCAM involving the right lung. His echocardiography, cranial and abdominal ultrasonography were all evaluated as normal. The infant was admitted to the neonatal intensive care unit due to respiratory distress and early surfactant therapy was performed after intubation. A chest tube was inserted as chest $X$-ray revealed a right pneumothorax. Chest computed tomography revealed millimetric cystic areas with septations in the lower lobe of the right lung leading to the postnatal diagnosis of CCAM (Figure 1). Pediatric surgeons operated him on the 14th postnatal day. CCAM in the superior segment of the lower lobe of the right lung was observed in addition to intrathoracic extralobar sequestration (ELS) at the level of the middle lobe which had no relation with the brochial tree and fed by the aorta. The pathology of the tissue also revealed CCAM type 2 in association with PS (Figure 2). The patient was extubated on the $23^{\text {th }}$ postnatal day. However, he was reintubated on the $28^{\text {th }}$ postnatal day due to respiratory distress associated with the recurrence of right pneumothorax. A right chest tube was inserted again, however, the resorbed pneumothorax relapsed on the 39th day and the respiratory symptoms of the patient worsened. Therefore, right lobectomy was performed by the pediatric surgeons. However, the patient died several days after surgery due to development of ventilator- associated pneumonia. Written informed consent was obtained from parents because the patient was below eigthteen years old.

\section{Discussion}

Congenital bronchopulmonary malformations are rare and present as congenital lobar emphysema, bronchogenic cyst, CCAM, and PS. Although PS and CCAM are well known entities, they are rarely seen in neonates. CCAM is more frequently seen in males, it is usually unilateral,

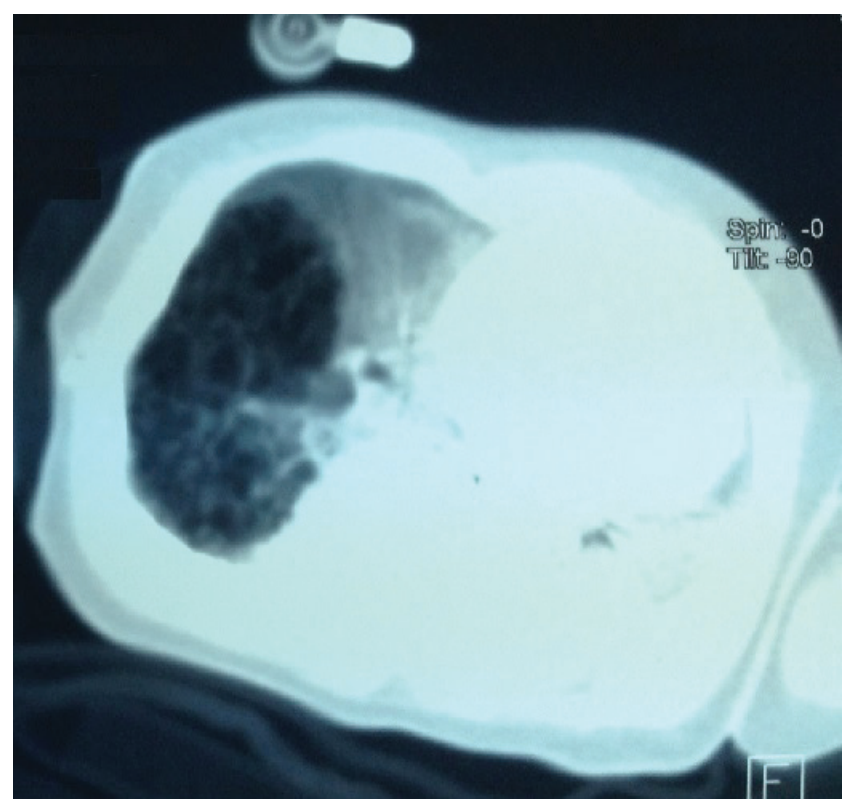

Figure 1. The chest computed tomography revealed milimetric cystic areas with septations in the lower lobe of the right lung

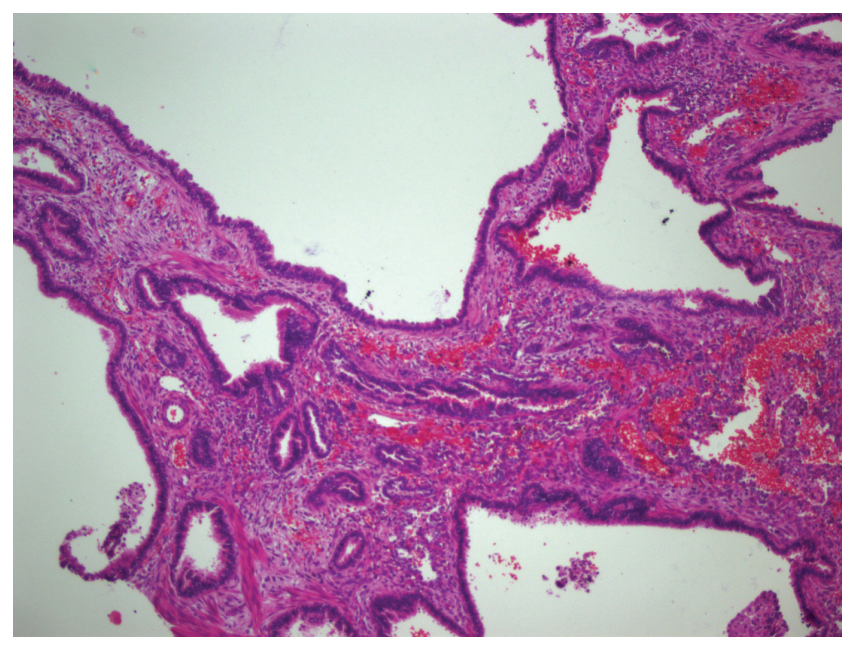

Figure 2. Right lung middle lobe distal segmentectomy: Cystic structures like bronchioles paved with cuboidal-columnar cells, asinus like structures associated with them, smooth muscle and cartilage around the bronchioles (hematoxylin and eosin stain, 100x) 
and involves only one lobe of the lung (1). There are five types of CCAM based on the embryologic level of origin and the histologic features (6). Diagnosis is more often made antenatally due to the increased use of obstetric USG. Perinatal mortality has been reported to vary between $10 \%$ and $35 \%$ in antenatally diagnosed CCAM $(7,8)$. Approximately $60 \%$ of CCAM cases are associated with other findings such as cardiac anomalies, renal agenesis/dysgenesis, gastrointestinal atresia, and skeletal anomalies (9). In accordance with the literature, our patient was male, had an antenatal diagnosis and CCAM was unilateral. He had no other organ anomalies. PS is even rarer and frequently associated with other anomalies compared to CCAM. Cases with ELS have been reported to be associated with abnormalities of the chest wall, diaphragm, lung, spine, intestine and the heart (10). The incidence of associated anomalies has been reported to be less frequent with intralobar sequestration (ILS) rather than ELS (11). Hybrid lesions were also defined as they contain the features of both CCAM and PS (6). CCAM and PS combination is seen much less frequently and cases of ELS constitute the majority of the reported cases in the literature. In their study including 50 cases of ELS, Conran and Stocker (4) reported that $48 \%$ of ELSs was located in the left and $20 \%$ in the right hemithorax with blood supply directly from the aorta in $77 \%$ of cases. Fifty percent of ELS cases were associated with a coexistent CCAM. ELS/ CCAM lesions were more frequently seen on the left side and $57 \%$ of cases occurred in females. All CCAM cases were found to have a type 2 pattern on histologic examination. In another report, five patients with the prenatal diagnosis of congenital lung abnormalities had an uneventful fetal life and were born uneventfully (12). Histopathologic examination revealed ILS with associated type 2 CCAM in two patients and ELS with associated type 2 CCAM in three patients. All patients except one, who presented with pneumonia at 10 months of age, were asymptomatic. This association has also been described since 1946 with 17 cases of ILS with CCAM and 19 cases of ELS with CCAM $(13,14)$. Approximately $80 \%$ of ELS receives its blood supply from the descending thoracic or abdominal aorta but the blood supply may also be from branches of a large vessel $(4,15)$. In a large series of infants, PS was reported to be more frequent in CCAM type 2 (16). Our patient was male and the combination of type 2 CCAM and ELS was in the right side with the blood supply directly from the aorta. Therefore, we suggest that the definition of hybrid lesions may show variations as the number of infants with this diagnosis increases. The natural history of antenatally diagnosed lung masses is variable. Presentation ranges from respiratory failure to a normally developing infant (17). Although about half of patients with a prenatal diagnosis of CCAM are asymptomatic at birth; patients with symptomatic CCAM can present with a history of recurrent pneumonia, cyanosis, respiratory distress, and pneumothorax (10). Patients with PS may be asymptomatic at birth, but can subsequently develop cough, hemoptysis, and recurrent pneumonia or can remain asymptomatic and can be diagnosed incidentally (10). ILS has been reported to be associated with chronic infections due to connections with the gastrointestinal tract, therefore, resection of the lesion is recommended regardless of the presence or absence of symptoms (18). In line with the literature, our case presented with severe respiratory distress and recurrent pneumothorax. Most authors recommend resection of all antenatally diagnosed CCAMs due to the risk of infection and of malignant transformation, although the surgery can be deferred for several months after birth (6). As ELS has not been reported to be associated with infection or malignant transformation, expectant management with serial imaging is usually recommended in asymptomatic patients. Resection is usually recommended in the case of respiratory compromise as it is considered to be curative (6). Surgical resection is recommended for hybrid lesions since these masses have a potential for recurrent infections (2). Our patient presented with respiratory distress due to pneumothorax in the immediate neonatal period which necessitated surgery during the first weeks of postnatal life, therefore, lobectomy was performed. However, in asymptomatic infants, surgical resection may be performed at 4-8 weeks of age with minimal morbidity and no mortality (19). Involution of PS/CCAM with significant systemic arterial blood supply is unlikely to occur which necessitates surgical excision of this congenital pulmonary lesion in order to avoid complications such as respiratory distress, infection, intrathoracic bleeding, haemoptysis, cardiac failure, and the potential risk of malignancy. Therefore, early surgery is suggested to reduce both morbidity and parental anxiety (12). The mortality rate was found to be $5 \%$ in a large series of infants, and most of them (58\%) had type 2 CCAM. Respiratory failure, sepsis and respiratory support requirements and severe associated comorbidities have been reported to be the risk factors for mortality (16). Our case had respiratory failure from birth with recurrent pneumothorax and mechanical ventilation requirement all of which may be associated with death. This case report is presented to emphasize that the association of PS with CCAM should be always kept in mind in the differential diagnosis of antenatal fetal lung masses. It is critical to establish the optimal surgery time and type in these infants. Hybrid lesions, especially type 2 CCAM and PS combination may have a more severe clinical progress. Both neonatologists and 
pediatric surgeons should be aware of the clinical features of CCAM, PS and hybrid lesions in both symptomatic and asymptomatic infants.

\section{Authorship Contributions}

Concept: B.C., M.Ç. Design: T.E.E. Data Colection or Processing: E.A Literature Search: A.B., G.B. Writing: B.C.

Conflict of Interest: No conflict of interest was declared by the authors.

Financial Disclosure: The authors declare that this study has received no financial support.

\section{References}

1. Shanti CM, Klein MD. Cystic lung disease. Semin Pediatr Surg 2008; 17:2-8.

2. Khalek N, Johnson MP. Management of prenatally diagnosed lung lesions. Semin Pediatr Surg 2013;22:24-9.

3. Imai Y, Mark EJ. Cystic adenomatoid change is common to various forms of cystic lung diseases of children: a clinicopathologic analysis of 10 cases with emphasis on tracing the bronchial tree. Arch Pathol Lab Med 2002;126:934-40.

4. Conran RM, Stocker JT. Extralobar sequestration with frequently associated congenital cystic adenomatoid malformation, type 2: report of 50 cases. Pediatr Dev Pathol 1999;2:454-63.

5. Davenport $M$, Eber E. Long term respiratory outcomes of congenital thoracic malformations. Semin Fetal Neonatal Med 2012;17:99-104.

6. Sfakianaki AK, Copel JA. Congenital cystic lesions of the lung: congenital cystic adenomatoid malformation and bronchopulmonary sequestration. Rev Obstet Gynecol 2012;5:85-93.

7. Laberge JM, Flageole $H$, Pugash $D$, et al. Outcome of the prenatally diagnosed congenital cystic adenomatoid lung malformation: a Canadian experience. Fetal Diagn Ther 2001;16:178-86.
8. Monni G, Paladini D, Ibba RM, et al. Prenatal ultrasound diagnosis of congenital cystic adenomatoid malformation of the lung: a report of 26 cases and review of the literature. Ultrasound Obstet Gynecol 2000;16:159-62.

9. Priest JR, Williams GM, Hill DA, Dehner LP, Jaffe A. Pulmonary cysts in early childhood and the risk of malignancy. Pediatr Pulmonol 2009;44:14-30.

10. Azizkhan RG, Crombleholme TM. Congenital cystic lung disease: contemporary antenatal and postnatal management. Pediatr Surg Int 2008;24:643-57.

11. Van Raemdonck D, De Boeck K, Devlieger H, et al. Pulmonary sequestration: a comparison between pediatric and adult patients. Eur J Cardiothorac Surg 2001;19:388-95.

12. Samuel M, Burge DM. Management of antenatally diagnosed pulmonary sequestration associated with congenital cystic adenomatoid malformation. Thorax 1999;54:701-6.

13. Cass DL, Crombleholme TM, Howell LJ, et al. Cystic lung lesions with systemic arterial blood supply: a hybrid of congenital cystic adenomatoid malformation and bronchopulmonary sequestration. J Pediatr Surg 1997;32:986-90.

14. Sakala EP, Perrott WS, Grube GL. Sonographic characteristics of antenatally diagnosed extralobar pulmonary sequestration and congenital cystic adenomatoid malformation. Obstet Gynecol Surv 1994;49:647-55.

15. Corbett HJ, Humphrey GM. Pulmonary sequestration. Paediatr Respir Rev 2004;5:59-68.

16. Giubergia V, Barrenechea $M$, Siminovich $M$, Pena $H B$, Murtagh P. Congenital cystic adenomatoid malformation: clinical features, pathological concepts and management in 172 cases. J Pediatr (Rio J) 2012;88:143-8.

17. Fitzgerald DA. Congenital cyst adenomatoid malformations: resect some and observe all? Paediatr Respir Rev 2007;8:67-76.

18. Laje P, Liechty KW. Postnatal management and outcome of prenatally diagnosed lung lesions. Prenat Diagn 2008;28:612-8.

19. Tsai $A Y$, Liechty $\mathrm{KW}$, Hedrick $\mathrm{HL}$, et al. Outcomes after postnatal resection of prenatally diagnosed asymptomatic cystic lung lesions. J Pediatr Surg 2008;43:513-7. 